\title{
The Will of Simon Jewell and the Queen's Men Tours in 1592
}

The will of Simon Jewell, a player of the Queen's Men who died in August 1592, was first discovered in 1974. The will, filled with information about the company's finances, has since been recognized as an invaluable source of evidence documenting useful details of the financial costs of an Elizabethan theatrical company. Despite its value as a historical document, however, the will has so far received somewhat cursory attention. This essay discusses this invaluable historical document with more careful attention to its details. It focuses on the company's costs and the actor's personal network in and outside the company, and investigates an implied local performance of the Queen's Men tours in the summer of 1592 in order to clarify its significance for theatre history.

\section{Simon Jewell as a Queen's Men player}

The will of Simon Jewell, a player of the Queen's Men who died in August 1592, was first discovered by Mary Edmond in 1974. ${ }^{1}$ The will is dated 19 August 1592 (see figure 1 for a reproduction of the will). His death seems to have followed shortly after the will was completed, as Jewell was buried at St Leonard Shoreditch on 21 August. His colleagues finally administered his will on 23 August. $^{2}$ Critics have since recognized the will, filled with information about the company's finances in which one of its sharers was involved, as an invaluable source of evidence documenting useful details of the financial costs of an Elizabethan theatrical company. ${ }^{3}$ Despite its value as a historical document, however, the will has so far received somewhat cursory attention. This inattention is partly the result of Jewell's virtually unknown career. The will obviously awaits further examination in its own right. This essay will discuss this invaluable historical document with more

Chiaki Hanabusa (chiaki@fbc.keio.ac.jp) is professor of English in the faculty of Business and Commerce at Keio University, Tokyo. 
careful attention to its details. It will focus on the company's costs and the actor's personal network in and outside the Queen's Men, and investigate an implied local performance in order to clarify its significance for theatre history.

Edmond first identified Jewell as a player for the Pembroke's Men because of a reference he makes to a payment, 'as shalbe givenn by my ladie Pembrooke or by her meanes. ${ }^{4}$ Scott McMillin challenged Edmond's theory by arguing that Jewell would more likely have been a member of the Queen's Men; his will includes the names of such eminent and minor players as 'mr Iohnson' (William Johnson), 'Roberte Nicholls', 'mr Smithe' (William Smith), and 'mr Cooke' (Lionel Cooke), all of whom are known, or are believed to have been, members of the Queen's Men. ${ }^{5}$ McMillin left the case of Lady Pembroke open owing to lack of conclusive evidence. Although theatre historians have not yet unanimously agreed on the question of Jewell's affiliation, the balance of probability tilts toward the Queen's Men in the light of existing scholarship. ${ }^{6}$ In the ensuing paragraphs, we will return to discuss the payment from Lady Pembroke by way of a more detailed analysis of his will and of what the payment reveals in the context of a local performance by the Queen's Men.

Presumably, Jewell died of the plague in the summer of 1592, with the seriousness of the epidemic growing daily from the middle of August to the end of the year. ${ }^{7}$ Unmarried and without children, he was concerned, on his sick bed, about the balance of his private finances. ${ }^{8}$ In his will, he first of all petitioned his company to pay back 'my share of apparrell the somm of thirteene pounde six shillinges eighte pence' and 'the sixth parte of thirtie seaven pounde ... my share for horses waggen and apparrell newe boughte'. Clearly, 'the sixth parte' indicates that one of the two groups of the company of which he was a member had six sharers as of summer 1592. 'The Queen's Men, established originally with twelve members in 1583 , is known in 1587-8 to have been split into two groups for touring the provinces separately, one half under John and Lawrence Dutton, the other half under John Laneham. ${ }^{10}$ As Laneham died in ca 1591, and Jewell does not mention him or either of the Dutton brothers, we do not know whether Jewell was in 1592 a member of the Duttons' or of ex-Laneham's group. Although we are not certain exactly how many original sharers, including the newly recruited ones, remained involved in the management of the whole company as of 1592, it is at least certain that there were six sharers in one of the two split groups. ${ }^{11}$ The will reveals that the six sharers of Jewell's group obtained the stock apparel by 
joint purchase, and that their total cost had the value of eighty pounds (ie, 'thirteene pounde six shillinges eighte pence' per sharer). The cost for the stock apparel was probably enormous, for we know that according to the regulation by royal proclamation (4 April 1590) the wages (with meat and drink) of 'the best and most skillful workmen, journeymen, and hired servants of any of the companies' ranged between four pounds and six pounds per year; with eighty pounds, one could have employed up to twenty skilful workmen for a year. ${ }^{12}$ Apparently, Jewell's reference to new horses, wagon, and apparel indicates that his group was either preparing to tour, or had just returned from the provinces. The sharers often paid for the company's extemporary needs such as when the apparel and/or travelling properties had to be newly purchased or replaced.

Jewell went on to entreat his company for the reimbursement of his deposit, that is, his share of the company. We know that Jewell had invested cash in the company and was involved in its management, although we do not know exactly when he became a sharer. As the investment of a sharer was considered part of his estate, customarily the deposited sum should have been reimbursed when he left the company with the consent of his fellow sharers, or to his wife on his death. ${ }^{13}$ Queen Anne's company, for instance, paid the widow of the prominent player Thomas Greene eighty pounds as his full share when he died in 1612, and agreed in 1618 to pay sixty pounds to another sharer, Robert Lee, on the condition that he fulfil the requirements stipulated by the company before he left. ${ }^{14}$ In a similar vein, the somewhat ambiguous sum that Jewell notes, 'xiiij li out of which my share is to be abated which commeth to fortie six shillinges eighte pence, and the residewe ... eleven pounde thirteene shillinges fouer pence', presumably, refers to the reduced sum of a share contracted to be paid back to the resigning sharer. ${ }^{15}$ The untitled payment looks more perplexing than the others in his will, but to those aware of the actor's finances and his daily life, the reference must have been evident. Two proctors administered Jewell's will, his fellow player William Smith and his landlord Robert Scott. ${ }^{16}$ They must have known what the unspecified sum actually was.

Jewell's will suggests that a full share of the Queen's Men cost fourteen pounds around 1592. This observation is substantiated by the fact that Philip Henslowe loaned Francis Henslowe, his nephew, fifteen pounds as 'his share to the Quenes players' on 8 May 1594, and by his other loan of nine pounds 'for his halfe share' of the same company on 1 June 1595.17 The cost of a full share of the Queen's Men seems to have inflated only slightly but steadily 
from fourteen pounds in 1592, to fifteen pounds in 1594, and to eighteen pounds in 1595.

For lack of evidence, one can only speculate on the reason for which 'my share is to be abated'. Nevertheless, the reduced payment could perhaps be accounted for in the following way: the payment Jewell expected to receive, that is, 'the residewe ... eleven pounde thirteene shillinges fouer pence', was exactly five-sixths of a full share. This fact suggests that the company's rule would have been that each sharer had to pay one-sixth of a full share when a sharer left the company with the others' consent. The abated refund intimates that his retirement, perhaps due to plague, was unexpected by the company, and that they may have been unable to recruit a new sharer to replace Jewell by the time he had completed his will. As a result, the company with only five sharers did not agree to a full refund. ${ }^{18}$ Jewell may have accepted the condition that he allow for the remaining one-sixth to be levied as a gift or donation to the Queen's Men.

Jewell further solicited that his fellow players pay 'eleven pounde thirteene shillinges fouer pence' to 'mr Brookes' at Christmas. Jewell went on to ask Master Brookes, 'vppon the paimente ... or presentlie after', to pay the sum, which is 'to my vse', to his landlord, Robert Scott. The identity of Master Brookes is not known, but he may possibly have been the 'trustee and manager' of the company; according to E.K. Chambers, this post is one to which 'one of the sharers should be appointed, formally or informally, ... to receive and make payments ... and generally to look after the business interests of his fellows. ${ }^{19}$ Scott, on the other hand, 'of Shordiche in the Countie of middlesex yeoman', ${ }^{20}$ may have had some acquaintance with the players who lived nearby, for we know that celebrities of the theatre lived in the parish of St Leonard Shoreditch. For instance, the Burbage family, including James, Richard, and Cuthbert, lived on Halliwell Street after 1576, and did not move even after the Theatre was dismantled. ${ }^{21}$ Richard Tarlton was buried there on 3 September 1588. That Scott was named as an executor in the will of John Bentley, another leading actor of the Queen's Men, in August 1585 is additionally suggestive. ${ }^{22}$ As Jewell, a lodger in Scott's house, was on his death-bed, the sum and purpose of the money 'to my vse' at Christmas seem unclear. He was probably concerned about his funeral costs, and hoped to pay them himself. Jewell's meticulous consideration for his landlord's family is clear from the fact that he bequeathed 'my blacke cloke lined with taffatie' to Robert, 'my livery coate' to his wife Eme, and 'five pounde' to their daughter Harris. ${ }^{23}$ 


\section{Jewell's Personal Network}

Jewell briefly stated that he owed to 'mr Matthewes five pounde', to ' $\mathrm{mr}$ Welshe mercer in Cheapeside Three pounde thirteene shillinges fouer pence', and to 'Richarde ffletcher fouer pounde'. Cheapside was the home of the Mercers' Company that specialized in the cloth trade, especially, in linens and velvets during the reign of Elizabeth I. The Mercers were also involved in exporting wool and importing fine fabrics such as silk. ${ }^{24}$ Jewell's debt for 'a paire of veluett hose thirtie shillinges' and his bequest, 'a black veluet purse imbrodered with golde and siluer', suggest some connection with 'mr Welshe mercer'. Unfortunately, we know now that there was no registered member of the Company with a surname of either Welsh(e), Welch(e), or Walsh(e) at any point throughout its history since $1347 .{ }^{25}$ Master 'Welshe mercer' may therefore possibly have belonged to a trade company other than the Mercers', as it was not uncommon that traders became, often by patrimony, members of a company different from their actual trade.

Richard Fletcher and Master Matthews, often erroneously labelled as actors, have never been identified. ${ }^{26}$ As a result critics have neglected the precise implication of the personal connection between Jewell and Fletcher, as well as that between Jewell and Matthews. My research has discovered that both Richard Fletcher and Master Matthews were fencing masters. According to Sloane ms 2530, the official document of the Company of Masters of Defence, one 'Richarde ffletcher' became 'Master of fence' at the 'prize' held at the Bull Inn in 1584 (for details of the 'prize', see below). ${ }^{27}$ Fletcher evidently outlived Jewell, for 'Richard Fletcher of Aldersgate Street London, Master of the noble science of Fence' is recorded in a contemporary local document to have accepted a legal obligation to pay ten pounds as recognizance on 1 November $1592 .^{28}$

The 'mr Matthewes' was possibly either William Matthews or John Matthews. William became master in the prize fight on tour in Canterbury on 5 June 1582, while John was awarded mastership at the Bell Savage Inn on 31 January 1589. ${ }^{29}$ William Matthews appears a number of times in Sloane Ms 2530, because he fenced against a candidate for mastership at the prize in $1583-9 .{ }^{30}$ In 1584, he was appointed as one of the masters to fight against Fletcher for his master's prize, and, along with Master Fletcher, William played the role of examiner of John Matthews for his mastership on 31 January 1589. William was still alive after Jewell's death, for on 1 December 1593 'William Matthewes master of fence ... of St. Sepulchre's in London' was 
recorded as having accepted his obligation for recognizance. ${ }^{31}$ Between 1604 and 1623, one 'William Mathewes', cutler of St Andrew's in Holborn, and his wife Helen, frequently appear as recusants in local records of London. ${ }^{32}$ One may well be tempted to identify the cutler with William Matthews in view of the cutler's trade. ${ }^{33}$ In 1569 , the Cutlers' Company became the trustees of the Bell Savage Inn where the prize was repeatedly held from the mid-1560s to 1589. The fact that the Cutlers' Company later obtained the freehold of the Bell Savage after the owner's death in 1591 would reinforce the speculation that William Matthews may have been the cutler. ${ }^{34}$ No evidence has yet come to light, however, to verify that the fencing master in question once was, or later became, a member of the Cutlers' Company: his name does not appear in 'The Roll of Members' which was compiled at the time of James's arrival as new reigning monarch in 1603 and which lists one hundred twenty cutlers, nor was it recorded in the list of the apprentices of the company. ${ }^{35}$ As John Matthews seems to have been long unheard of after 1589, the evidence stops short of clarifying whether ' $m r$ Matthewes' was William or John. ${ }^{36}$

Sloane ms 2530 contains the record of ninety-five prizes in all. The 'prize', supervised by the Company of Masters of Defence, was the official probation, or examination, of fencing skills for the company's students. They were, if successful, conferred the title of free scholar, provost, and master. ${ }^{37}$ The prize was open to the public and was performed as a fencing show at a variety of venues mainly in London from c1540. ${ }^{38}$ Inns and the theatres in 1559-90 frequently hosted the event, such as the Bull Inn (twenty-one times), the Bell Savage (eleven), the Curtain (seven), and the Theatre (six). ${ }^{39}$ Contemporary authors often described the event. In the first edition of $A$ Perambulation of Kent (1576), William Lambarde mentioned some London stages that players and fencers commonly used, such as 'Parisgardein, the Bell Sauage, or some other suche common place, to beholde Bearebayting, Enterludes, or fence playe'. Twenty years later, his second revised and enlarged edition (1596) replaced 'some other suche common place' with 'Theatre', suggesting that the fencing show on the London stages continued to flourish into the mid1590 s. ${ }^{40}$ Dramatists also referred to fencers and their prize fights, proof that fencing shows were prevalent among the London audience. In the first act of Titus Andronicus (1594), Saturninus says to Bassianus and Lavinia, 'you haue plaid your prize', in order to concede to them that Bassianus had engaged in the contest and won Lavinia (C1v). ${ }^{41}$ Slender confesses, in the Folio text of Merry Wives of Windsor (1623), that he broke his shin the other day because he played 'at Sword and Dagger with a Master of Fence' (D3r). ${ }^{42}$ 


\section{Jewell and Fencing}

Just as the dramatists had to meet the audience's expectations for fencing scenes in their plays, the actors needed to acquire superb fencing techniques to perform the stage duels and battles. The level of brilliance expected by the London audience was high: not only were attendees familiar with professional fencing through the prizes from the 1570s onwards, but also some of them had actually been trained at fencing schools by famous masters from Italy or Spain. ${ }^{43}$ The publication of books on the art of fencing in the 1590s must have furthered the readers' familiarity with skilful fencing. ${ }^{44}$ As Ian Borden rightfully argues, 'Actors were trained in fencing, and writers utilized the audience's expectation of skilled swordplay'. Shakespeare is known for being quite precise in describing, with relevant technical terminology, the fight scene in Romeo and Juliet where Mercutio subscribes to the Italian school but Tybalt to the Spanish. ${ }^{45}$ Thus, actors, especially adult players, would have been willing to learn those skills from a master of fencing to show their artistry and proficiency on stage to attract and entertain the audience. ${ }^{46}$

The close connection between contemporary actors and fencing masters can be suggested by the fact that Tarlton, trained under Henry Nayler, was awarded mastership by the Company of the Masters of Defence on 23 October $1587 .{ }^{47}$ Tarlton was not the only actor/fencer of his company. When the Queen's Men played at the Red Lion in Norwich on the afternoon of 15 June 1583 , an affray took place at the gate, where the gatekeeper argued with a man about his entrance fee. Tarlton attempted to come down from the stage but was detained; John Bentley, one of the leading actors of the company, then playing the Duke, came down instead and pursued the man with a stage sword 'to demonstrate his fencing skill'. Bentley finally caught up with him, and 'thrust at him twice with his naked rapier'. ${ }^{48}$ Scholars have identified the actors of Shakespeare's company, Richard Burbage, Thomas Pope, and William Sly, as a group of players with considerable fencing skills, and presumably the dramatist 'consciously planned his plays to utilize the three good fencers in the main fencing parts'. 49

The shared use of the stage at the Bell Savage, the Bull, and the Curtain by the Company of Masters of Defence and the theatrical companies from the 1570 s to the 1580 s, as well as the fact that the adult players in London needed to acquire advanced fencing skills, makes it hard to reject the possibility that the actors and the fencing masters came to know each other, and 
kept up their acquaintance both in and out of the theatres. The Queen's Men players were no exception; they must have needed the fencing skills. Of the nine extant plays which Scott McMillin and Sally-Beth MacLean identify as part of the company stock, ${ }^{50}$ Famous Victories of Henry the Fifth (1598) refers to a fencing school ('ile turne all these prisons into fence Schooles'), while it mentions in a stage-direction, 'The Battell'. Battle scenes with the use of weapons are suggested in some other Queen's plays such as Friar Bacon and Friar Bungay (1594) - 'Enter Lambert and Serlsbie, with Rapiers and daggers'; 'They fight and kill ech other') — Selimus (1594) — 'They fight. He killeth Cherseoli, and flieth') - The True Tragedie of Richard the Third (1594) The battell enters, Richard wounded, with his Page') - and Clyomon and Clamydes (1599) - 'Here let them fight, the King fall downe dead'. ${ }^{1}$

Michela Calore has pointed out that the battle scenes these stage directions represent are concentrated, in general, 'in the plays of the 1580s and 1590s'.52 The date coincides with the period when the fencing masters most flourished in London then gradually began to decline, as evidenced by the fact that Sloane ms 2530 concludes in 1590. In the age of fencing and the masters of fence, the majority of the audience would have applauded onstage battles presented physically rather than through an exchange of words. McMillin and MacLean superbly corroborate this assertion by arguing that the battle scenes in the Queen's Men's plays were 'wordless battles set apart from moment of speech, as though the battles were thought of as having a text of their own .... There is little sign in their extant repertory of the experiments that were being tried in Shakespeare's plays on Henry VI, where battle scenes ebb and flow with full-fledged dialogue among contenders. ${ }^{53}$ The Queen's Men were accustomed to showing on stage real fighting between experienced players skilled in the use of swords and rapiers, rather than mock-fights enhanced by sophisticated dialogues.

Under the circumstances, it would seem natural that Jewell became friends with the two masters of fence, as he regularly had to fight on stage. Jewell's connection with the fencers, reflected in his debt of four and five pounds to each, would suggest the informal nature of his relationship, for his debt to them is evidently high; of his total debts, that is, 'nyneteene pounde twelve shillinges nine pence', it constitutes approximately half (45.8 per cent). It would be tempting to hypothesize, although it is hard to verify, that Jewell as a Queen's Men player may have learned his fencing skills from Richard Fletcher and Master Matthews. One may well recall that Tarlton was trained by his fencing master Henry Nayler while he was still an active player. The 
geographical proximity of the venues and the common interests in fencing skills for the stage fight and for the prize naturally would have driven the actors and the fencing masters to keep up their relationship.

\section{Jewell and Lady Pembroke}

Finally, let us return to Jewell's will. Current scholarship has left unsolved the problem of 'my ladie Pembrooke', as I mentioned above. So far as we know from surviving provincial records of payments to the Elizabethan dramatic companies, one of the troupes of the Queen's Men received two pounds in Bristol between 2 and 15 July 1592, ${ }^{54}$ while the other group travelled towards the north from Norwich (performance dismissed, forty shillings paid on 27 May), to Cambridge (dismissal, twenty shillings paid, 10 June), then to Leicester (more than forty shillings paid, after 10 June), and to York (three pounds six shillings eight pence and twenty shillings paid, 24 July). ${ }^{55}$ Leaving Bristol, the troupe travelling southward seems to have visited Southampton (forty shillings paid, 3 August), ${ }^{56}$ Winchester (twenty shillings paid, August?), ${ }^{57}$ and Bath (fourteen shillings nine pence paid, ca 22 August). ${ }^{58}$ Furthermore, an undated payment recorded in Gloucester (thirty shillings plus breakfast worth nine shillings five pence, paid between 22 May and 4 August $)^{59}$ may perhaps indicate their visit there. On the basis of these provincial records, it seems sound to infer, though not fully evident for lack of the exact dates of performance, that a troupe of the Queen's Men was travelling in the south-west from July to August of 1592, just before Jewell's death. Even the conjectured performance in Bath (ca 22 August) may have occurred before Jewell died, because the date of payment does not necessarily indicate the date of performance or visit. Recorded payments were, in some or most cases, deferred reimbursements by a third party. Such reimbursements were, as Giles E. Dawson notes of those recorded in Kent, 'sometimes deferred for weeks or months'. Accordingly, we must assume that the date of an entry provides a terminus ad quem of the performance at best. ${ }^{60}$ The London theatres were closed from 23 June 1592 due to a disorder in Southwark, ${ }^{61}$ and except for sporadic performances not reopened until 1594 due to the subsequent plague, so that it was undoubtedly a reasonable decision for the Queen's Men players to leave the capital for two separate provincial tours.

The geographical proximity of the cities above suggests that in July-August 1592 one troupe was travelling round the south-west including Gloucestershire (Gloucester), Somersetshire (Bath and Bristol), and Hampshire 
(Southampton and Winchester). Bordering on the three counties is Wiltshire, where Wilton House, home of Mary Herbert, née Sidney, Countess of the second Earl of Pembroke, Henry Herbert, was located. Mary was a renowned writer known to have been generous in giving patronage to poets, notably to Samuel Daniel, Thomas Churchyard, and, later, John Aubrey. Nicholas Breton, Thomas Nashe, and Abraham Fraunce sought her patronage, while Daniel, Shakespeare, Edmund Spenser, John Donne, and others celebrated her writings and some borrowed from them. ${ }^{62}$ While achieving public recognition as a patroness, she preferred to stay with the members of her literary coterie. Chambers notes that she seems to have spent 'most of her time ... at her husband's Wiltshire seats of Wilton, Ivychurch, and Ramsbury'. ${ }^{63}$ In the summer of 1592, especially during August, in order not only to avoid the outbreak of plague in London but also to prepare for Queen Elizabeth's visit to her residence at Ramsbury, which was scheduled on 26-8 August, ${ }^{64}$ Mary very likely stayed, not in London or elsewhere, but in Wiltshire.

The Sidney family had a long tradition of supporting popular drama. Mary's husband followed this tradition and continued to encourage dramatic productions. There was a flurry of performances at Ludlow Castle and Shrewsbury, the primary residences of his office, especially in the 1590s. Ten companies produced the performances including the Queen's, Lord Strange's, Worcester's, Essex's, and Pembroke's Men. ${ }^{65}$ Mary herself enjoyed the entertainments in her childhood, such as the Robin Hood plays and folk songs by singers and minstrels. ${ }^{66}$

The facts that Wiltshire shares borders with Gloucestershire, Somersetshire, and Hampshire, that Mary served as a patron for her literary circle and the Sidney family had a tradition of offering support to dramatic companies, that she was most likely in Wiltshire at the time, and that Jewell refers to Mary in his will cumulatively suggest that one of the Queen's Men troupes, of which Jewell was a member, may have performed at Mary Herbert's residence around July-August 1592. The long gap of one month between 19 August when Jewell completed his will, and 18 September when one of the company's troupes appeared again in Cambridge for their autumn tour ${ }^{67}$ suggests that the 'horses waggen and apparrell newe boughte' were most likely used as touring properties for Jewell's group in the south-western tour that summer.

The reference to Lady Pembroke, which reads 'my share of suche money as shalbe givenn by my ladie Pembrooke or by her meanes', now becomes less obscure. Rather than forming the basis of the argument that Jewell was 
a member of the Pembroke's Men, it points instead to Mary's payment to the Queen's Men for their performance at her Wiltshire residence. This remuneration would have been an example of deferred imbursement by a third party, as is clear from the phrase, 'by her meanes'. MacLean, most recently in 2009, has suggested that 'The anticipation of Jewell's share in money to come from Lady Pembroke implies either that the company may have been commissioned to perform at one of her family residences or that they had earned her special approval'. ${ }^{68}$ Her suggestion would be reinforced by my argument that the performance at Mary's residence had already taken place in the midsummer of 1592, just before Jewell completed his will. My claim largely coincides with an inference made by Karl P. Wentersdorf more than thirty years ago. Without identifying Jewell's affiliation to the Queen's Men, he claimed that 'his company, whoever their patron, had performed before her and her household shortly before 19 August 1592, and that the promised or anticipated payment had not yet been received by the players. ${ }^{69}$ Admittedly it depends on a series of assumptions, but my fresh research of Jewell's will and of the extant records of the south-western provinces seems to refine his claim further that one of the two Queen's Men troupes, of which Jewell was an actor/sharer, performed before Lady Pembroke at one of her residences in Wiltshire in July-August 1592, but that the sum would not yet have been paid to them on 19 August, the date when Jewell's will was completed.

Perhaps the journey to the south-west with the 'horses waggen and apparrell newe boughte' was his final provincial tour. The memory of Mary Herbert and of the travel and performance may have been fresh in his mind when he was on his death bed, for his note on Lady Pembroke's payment is the last item inscribed in his will. That memory was unable to bring his career as a Queen's Men player to a sound end. Young and without a family, Jewell had to face the sad final duty of arranging for his share of Lady Pembroke's reward to be 'distributed and paide towardes my buriall and other charges'. 

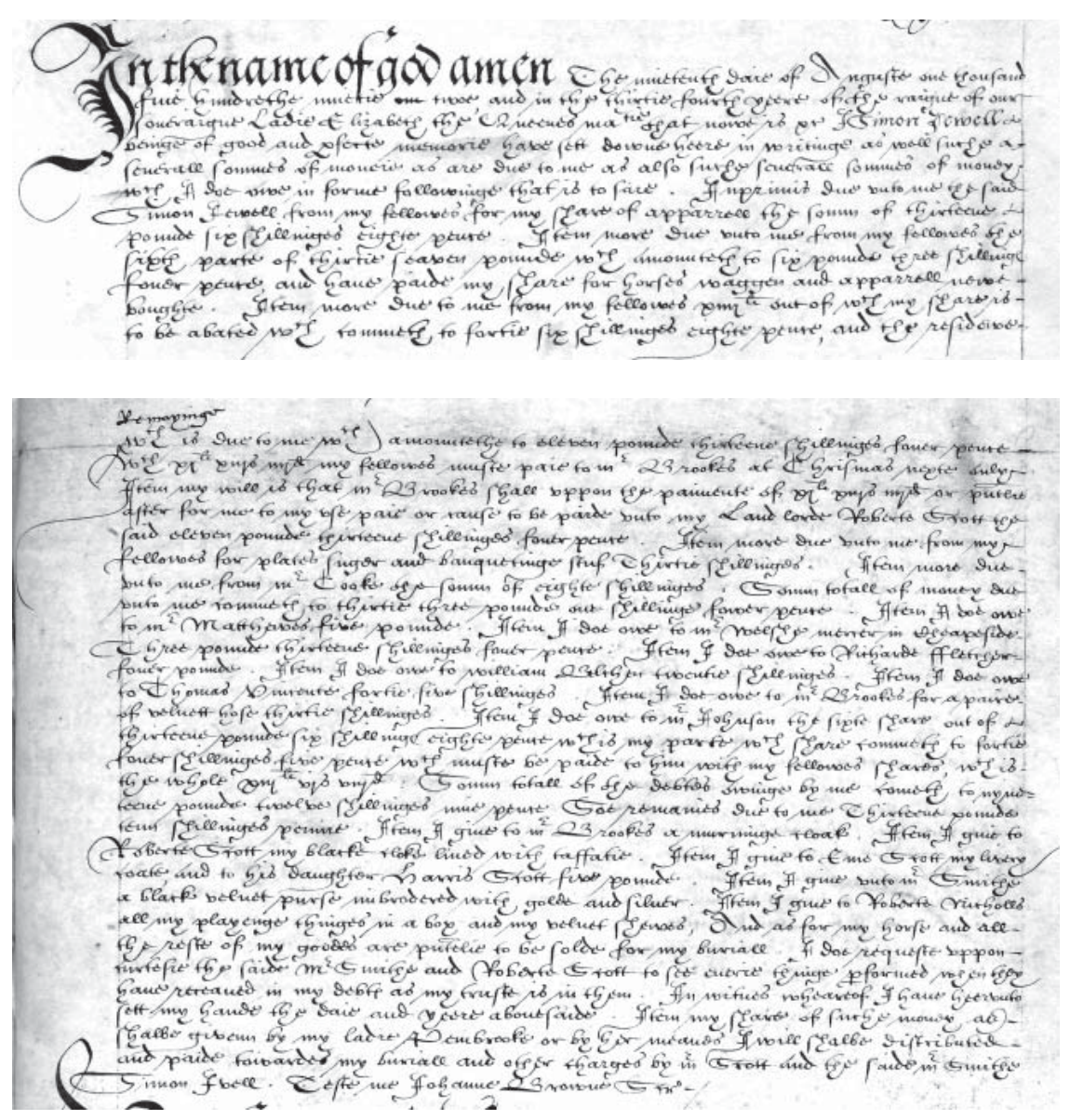

Figure 1. Reproduction of Simon Jewell's Will. (PROB 11/80, fols 130v-131r, The National Archives. Reproduced with permission of TNA.) 


\section{Appendix}

Transcript of Simon Jewell's will, from E.A.J. Honigmann and Susan Brock (eds), Playhouse Wills 1558-1642: An Edition of Wills by Shakespeare and His Contemporaries in the London Theatre (Manchester, 1993), 58-60.

\section{Aug. 19 Simon JEWELL}

In the name of god amen The nineteenth daie of Auguste one thousand fiue hundrethe ninetie [one] twoe, and in the thirtie fourth yeere of the raigne of our soueraigne Ladie Elizabeth the Queenes maiestie that nowe is \&c I Simon lewell beinge of good and perfecte memorie have sett downe heere in writinge as well suche seuerall sommes of moneie as are due to me as also suche seuerall sommes of money which I doe give in forme followinge that is to saie. Inprimis due vnto me the said Simon Iewell from my fellowes for my share of apparrell the somm of thirteene pounde six shillinges eighte pence. Item more due vnto me from my fellowes the sixth parte of thirtie seaven pounde which amounteth to six pounde three shillinges fouer pence, and haue paide my share for horses waggen and apparrell newe boughte. Item more due to me from my fellowes xiiij li out of which my share is to be abated which commeth to fortie six shillinges eighte pence, and the residewe (fo. 131r) \{Remayinge\} which is due to me which amountethe to eleven pounde thirteene shillinges fouer pence which xj li xiij s iiij $\mathrm{d}$ my fellowes muste paie to $\mathrm{mr}$ Brookes at Christmas nexte only Item my will is that $\mathrm{mr}$ Brookes shall vppon the paimente of xj li xiij s iiij d or presentlie after for me to my vse paie or cause to be paide vnto my Land lorde Roberte Scott the said eleven pounde thirteene shillinges fouer pence. Item more due vnto me from my fellowes for plates suger and banquetinge stuf Thirtie shillinges. Item more due vnto me from $\mathrm{mr}$ Cooke the somm of eighte shillinges. Somm totall of money due vnto me commeth to thirtie three pounde one shillinge fower pence. Item I doe owe to $\mathrm{mr}$ Matthewes five pounde. Item I doe owe to $\mathrm{mr}$ Welshe mercer in Cheapeside Three pounde thirteene shillinges fouer pence. Item I doe owe to Richarde ffletcher fouer pounde. Item I doe owe to william Belchen twentie shillinges. Item I doe owe to Thomas Vincente fortie five shillinges. Item I doe owe to $\mathrm{mr}$ Brookes for a paire of veluett hose thirtie shillinges. Item I doe owe to $\mathrm{mr}$ Iohnson the sixte share out of thirteene pounde six shillinge eighte pence which is my parte which share commeth to 
fortie fouer shillinges five pence which muste be paide to him with my fellowes shares, which is the whole xiij li vj s viij d: Somm totall of the debtes owinge by me cometh to nyneteene pounde twelve shillinges nine pence Soe remaines due to me Thirteene pounde tenn shillinges pennie. Item I giue to $\mathrm{mr}$ Brookes a murninge cloak. Item I giue to Roberte Scott my blacke cloke lined with taffatie. Item I giue to Eme Scott my livery coate and to his daughter Harris Scott five pounde. Item I giue vnto $\mathrm{mr}$ Smithe a black veluet purse imbrodered with golde and siluer. Item I giue to Roberte Nicholls all my playenge thinges in a box and my veluet shewes, And as for my horse and all the reste of my goodes are presentelie to be solde for my buriall. I doe requeste vppon curtesie the saide $\mathrm{Mr}$ Smithe and Roberte Scott to see euerie thinge performed when they haue receaued in my debtes as my trust is in them. In witness wheareof I haue heervnto sett my hande the daie and yeere abouesaide. Item my share of suche money as shalbe givenn by my ladie Pembrooke or by her meanes I will shalbe distributed and paide towardes my buriall and other charges by mr Scott and the saide mr Smithe Simon Ivell. Teste me Iohanne Browne Scriuener.l

\section{Notes}

1 Mary Edmond, 'Pembroke's Men', The Review of English Studies 98 (1974), 12936. DOI: http://dx.doi.org/10.1093/res/XXV.98.129, in which she transcribed the will (TNA PROB 11/80, fols 130v-131r). The will was transcribed again with some additional notes in E.A.J. Honigmann and Susan Brock (eds), Playhouse Wills 1558-1642: An Edition of Wills by Shakespeare and His Contemporaries in the London Theatre (Manchester, 1993), 58-60, which corrects Edmond's minor transcription errors. All citations of Jewell's will are from this edition.

2 Honigmann and Brock, Playhouse Wills, 60.

3 The will keeps drawing the interests of critics. Andrew Gurr, for example, recently referred to it in his updated edition of The Shakespearean Stage 1574-1642, 4th edn (Cambridge, 2009), 52. See also Sally-Beth MacLean, 'Adult Playing Companies 1583-1593', Richard Dutton (ed.), The Oxford Handbook of Early Modern Theatre (Oxford, 2009), 39-55, esp. 44-5. DOI: http://dx.doi.org/10.1093/oxford$\mathrm{hb} / 9780199697861.013 .0003$

4 For all references to Jewell's will, see the transcription in the appendix.

5 Scott McMillin, 'Simon Jewell and The Queen's Men', The Review of English Studies 106 (1976), 174-7. DOI: http://dx.doi.org/10.1093/res/XXVII.106.174 
6 Gerald Eades Bentley submitted an endorsement for McMillin's argument, in The Profession of Player in Shakespeare's Time 1590-1642 (Princeton, 1984), 4. McMillin and Sally-Beth MacLean later enforced the point more persuasively in The Queen's Men and their Plays (Cambridge, 1998), 29-30. For critics who sanction Edmond's identification, see David George, 'Shakespeare and Pembroke's Men', Shakespeare Quarterly 32 (1981), 305-23. DOI: http://dx.doi.org/10.2307/2870248; Gurr, Shakespearean Stage, 52.

7 The first notice of the plague was on 13 August, six days before Jewell's decision to write his will. See E.K. Chambers, The Elizabethan Stage, 4 vols (Oxford, 1923), 4.347 .

8 Jewell never mentioned his wife and children in his will, as two Queen's Men players, John Bentley (d. 1585) and Richard Tarlton (d. 1588), did in their wills. See Honigmann and Brock, Playhouse Wills, 55-8.

9 I mention in passing that the use of 'sharer', rather than 'shareholder', is more standard in the context of the Elizabethan theatre history.

10 G.M.Pinciss, 'TheQueen'sMen, 1583-1592', TheatreSurvey11 (1970), 50-65, esp. 589. DOI: http://dx.doi.org/10.1017/S0040557400007511; Andrew Gurr, The Shakespearian Playing Companies (Oxford, 1996), 204-5. DOI: http://dx.doi.org/10.1093 lacprof:oso/9780198129776.001.0001; McMillin and MacLean, Queen's Men and their Plays, 44.

11 Only five of the original twelve members stayed in the company till 1592: John Dutton, John Towne, John Synger, Lionel Cook, and John Garland. In addition, in 1592, the Queen's Men included, at least, the following personnel: John Heminges (joined 1588, the Strange's from 6 May 1593), Lawrence Dutton (joined by 1588 until 1594), Robert Nichols, William Smith, and Thomas Vincent (Jewell mentioned all three). See the relevant entries in Edwin Nungezer, A Dictionary of Actors (New Haven, 1929), the alphabetical list of the players in Mark Eccles, 'Elizabethan Actors' in Notes and Queries 38-40 (1991-3), and David Kathman's 'Biographical Index of English Drama Before 1660' (http://shakespeareauthorship.com /bd/). See also William Ingram, 'Lawrence Dutton, Stage Player: Missing and Presumed Lost', Medieval and Renaissance Drama in England 14 (2001), 122-43, esp. 122.

12 Paul L. Hughes and James F. Larkin (eds), Tudor Royal Proclamations, 3 vols (New Haven, 1969), 3.40, 59.

13 Gurr, Shakespearean Stage, 87.

14 Bentley, The Profession of Player, 29-30; Gurr, Shakespearean Stage, 86-7. 
15 Theatre historians have scarcely been loquacious in arguing about this payment. As far as I know, only David George brought attention to this payment, in his 'Shakespeare and Pembroke's Men', 307-8.

16 Honigmann and Brock, Playhouse Wills, 60.

17 R.A. Foakes (ed.), Henslowe's Diary, 2nd edn (Cambridge, 2002), 7, 9. The company's name is unspecified by Henslowe in the second loan to Francis, but all three players who endorsed it are believed to have belonged to the Queen's Men.

18 Gurr points out that a sharer could receive repayment of his share 'when he left, providing he left with the agreement of his fellow sharers', in Shakespearean Stage, 87.

19 Chambers, Elizabethan Stage, 1.352-3.

20 Honigmann and Brock, Playhouse Wills, 56.

21 Roslyn Lander Knutson, Playing Companies and Commerce in Shakespeare's Time (Cambridge, 2001), 33-4. DOI: http://dx.doi.org/10.1017/CBO9780511486043

22 Honigmann and Brock, Playhouse Wills, 56; Gerald Eades Bentley, 'The Wills of Two Elizabethan Actors', Modern Philology 29 (1931), 110-14. DOI: http://dx.doi .org/10.1086/387948

23 We know that one Robert Scott 'died within the gaol ... after seven days of illness' on 11 April 1595, but the identity is uncertain. See John Cordy Jeaffreson (ed.), Middlesex County Records (Old Series), 4 vols (London, 1972), 1.227.

24 Ian Doolittle, The Mercers' Company 1579-1959 (London, 1994), 18, 24, respectively.

25 The member with the surname 'Welshe' is not recorded in A List of Some Eminent Members of the Mercers Company of London (London, 1872). I am grateful to Donna Marshall, Assistant Archivist of the Mercers' Company, for very kindly checking all the members including masters, wardens, court of assistants, and apprentices, and for informing me of the invaluable information that there has been no member with the surname 'Welsh' and its variant forms in the company's history.

26 In her 'Pembroke's Men', 132-3, Edmond suggested that Richard Fletcher was possibly an actor and 'may have been the man of that name - yet another resident of Holywell-street - who had married Joan Halliwell at the parish church on 18 January 1578/9', based on Guildhall Library, 7493. David George suggested that Master Matthews was an actor, in his 'Shakespeare and Pembroke's Men', 308.

27 Sloane ms 2530, fol. 4. See Herbert Berry, The Noble Science: A Study and Transcription of Sloane MS. 2530, Papers of the Masters of Defence of London, Temp. Henry VIII to 1590 (Newark, 1991), 49.

28 Jeaffreson, Middlesex County Records, 1.210. 'Recognizance' was generally a sum of money paid before a court or magistrate as a surety to 'perform some act or observe 
some condition (as to appear when called on, to pay a debt, or to keep the peace)' and 'rendered forfeit by neglect of it' (OED, 3rd edn, 'recognizance', n.1). But the recognizance here means Fletcher's legal obligation to pay ten pounds if a certain person summoned would not appear at the next court session.

29 Berry, Noble Science, 47, 55.

30 Ibid, 49, 51, 53, 55.

31 Jeaffreson, Middlesex County Records, 1.218.

32 Ibid, 2, 6, 78, 106, 109, 113-14, 127-8, 146, 237.

33 Some cutlers were skilful fencers. See an anonymous play acted by the Cambridge University students, Worke for Cvtlers, or A Merry Dialogve betweene Sword, Rapier, and Dagger (London, 1615; sTC: 25981), where the cutler is depicted as 'a man as well Armed as any man I knowe, and has as good skill ins weapons' (B1r).

34 For the eminent joint owners of the Bell Savage from 1555 to 1591, namely John Craythorne, cutler, and his wife Margaret, and its lease to the Cutlers' Company, see Herbert Berry, 'The Bell Savage Inn and Playhouse in London', Medieval \& Renaissance Drama in England 19 (2006), 121-43.

35 Charles Welch (ed.), History of the Cutlers' Company of London and of the Minor Cutlery Crafts with Biographical Notices of Early London Cutlers, 2 vols (London, 1923), 2.303; Cliff Webb, London Livery Company Apprenticeship Registers: Cutlers' Company 1442-8, 1565-1800, vol. 35 (London, 2001). I am indebted to Dr Geoff Swinfield of the Library of the Society of Genealogists for Matthews's absence from this volume by private correspondence.

36 The absence of evidence would not rule out the possibility that the fencing master became a freeman of the company by marriage with a cutler's widow, or by translation after being freed from another company by servitude or patrimony, or by paying the redemption fee, of forty shillings. For details of the admission to the company, see Welch, History of the Cutlers' Company, 2, 13, 65-6, 70.

37 Berry, Noble Science, 25-6.

38 The second edition of $O E D$ defines 'fencer' as 'One who fences in public shows; a hired or professional swordsman' ('fencer', 1.b)

39 For the number of prizes held in the London venues, see O.L. Brownstein, 'A Record of London Inn-Playhouses from c.1565-1590', Shakespeare Quarterly 22 (1971), 17-24, esp. 18.

40 See William Lambarde, A Perambulation of Kent: Conteining the Description, Hystorie, and Customes of That Shyre (London, 1576; sTC: 15175-15715.5), 187; the second edition (London, 1596; sTC: 15176), 233.

41 The Most Lamentable Romaine Tragedie of Titus Andronicus (stc: 22328). The first act is currently believed to have been written by Shakespeare's collaborator, George 
Peele. See MacDonald P. Jackson, 'Stage Directions and Speech Headings in Act 1 of Titus Andronicus Q (1594): Shakespeare or Peele?', Studies in Bibliography 49 (1996), 134-48; 'Shakespeare's Brothers and Peele's Brethren: Titus Andronicus Again', Notes and Queries 242 (1997), 494-5. DOI: http://dx.doi.org/10.1093/ notesj/44.4.494; 'Indefinite Articles in Titus Andronicus, Peele, and Shakespeare', Notes and Queries 243 (1998), 308-10. DOI: http://dx.doi.org/10.1093/nq/45.3.308

42 See the First Folio (sTC: 22273). Slender, in its quarto edition (London, 1602; sTC: 22299), goes into further details: 'I with my ward Defending my head, he hot [ie hit] my shin. Yes faith.' (A4v).

43 The most popular fencing master was the Italian, Rocco Bonetti, who came to London in ca 1569 and died in 1587. He founded his 'College' in the property in Blackfriars, which later became part of the first Blackfriars Theatre. See Jay P. Anglin, 'The Schools of Defence in Elizabethan London', Renaissance Quarterly 37 (1984), 393-410, esp. 409. DOI: http://dx.doi.org/10.2307/2860956

44 See, for example, Giacomo di Grassi, Giacomo di Grassi His True Arte of Defence (London, 1594; STC: 12190); Vincentio Saviolo, Vincentio Saviolo His Practise ... of the Use of the Rapier and Dagger (London, 1595; sтс: 21788-9); and George Silver, Paradoxes of Defence (London, 1599; sTC: 22554).

45 Ian Borden, 'The Blackfriars Gladiators: Master of Fence, Playing a Prize, and the Elizabethan and Stuart Theater', Paul Menzer (ed.), Inside Shakespeare: Essays on the Blackfriars Stage (Susquehanna UP, 2006), 132-46, esp. 138, 143; Adolph L. Soens, 'Tybalt's Spanish Fencing in Romeo and Juliet', Shakespeare Quarterly 20 (1969), 121-7. DOI: http://dx.doi.org/10.2307/2868996

46 For the flourishing of the Elizabethan stage battle and sword fight, as well as the historical accounts of wrestling match and pike-tossing, see Louis B. Wright, 'Stage Duelling in the Elizabethan Theatre', Modern Language Review 22 (1927), 265-75. DOI: http://dx.doi.org/10.2307/3714638

47 Berry, Noble Science, 53. Tarlton's mastership was awarded not as the result of the prize fight but by agreement of masters (33).

48 Bentley, 'The Wills', 111. For the detailed accounts of the accident, see Glynne Wickham, Herbert Berry, and William Ingram (eds), English Professional Theatre, 1530-1660 (Cambridge, 2000), 246-50.

49 James L. Jackson, 'The Fencing Actor-Lines in Shakespeare's Plays', Modern Language Notes 57 (1942), 615-21. DOI: http://dx.doi.org/10.2307/2910517

50 The nine plays comprise Clyomon and Clamydes, The Famous Victories of Henry the Fifth, Friar Bacon and Friar Bungay, The Three Lords and Three Ladies of London, The Troublesome Reign of King John, Selimus, King Leir, The Old Wives' Tale, and The 
True Tragedy of Richard the Third. See McMillin and MacLean, Queen's Men and their Plays, 88-94.

51 See Anonymous, The Famous Victories of Henry the Fifth (stc: 13072), C1r, F1r; Robert Greene, The Friar Bacon and Friar Bungay (sтc: 12267), H1v-H2r; Anonymous, Selimus (stc: 12310a), C4v; The True Tragedy of Richard the Third (sTc: 21009), H3r; Peele, Clyomon and Clamydes (stc: 5450a), F2r.

52 Michela Carole, 'Battle Scenes in the Queen's Men's Repertoire', Notes and Queries 248 (2003), 394-9, esp. 395.

53 McMillin and MacLean, Queen's Men and their Plays, 129.

54 Mark C. Pilkinton (ed.), REED: Bristol (Toronto, 1997), 142. See also 'The Patrons and Performances Web Site' of University of Toronto's REED project (http://link .library.utoronto.ca/reed/). The original record reads 'Item paid vnto the Queenes Maiesties plaiers that plaied before master mayor and Thalldermen ij li.'

55 See David Galloway (ed.), REED: Norwich 1540-1642 (Toronto, 1984), 102; Alan H. Nelson (ed.), REED: Cambridge (Toronto, 1989), 1.338; McMillin and MacLean, 'Appendix A: Recorded Performances of the Queen's Men', in their Queen's Men and their Plays, 182; Alexandra F. Johnston and Margaret Rogerson (eds), REED: York (Toronto, 1979), 1.449, 451.

56 The 'Book of Fines' in Mayor's Accounts, 238r. See C.E.C. Burch, Minstrels and Players in Southampton 1428-1635, Southampton Papers 7 (Southampton, 1969), 44. The REED volume of Hampshire is forthcoming.

57 'The Chamberlain's Account' (W/E1/109) in Hampshire Record Office shows that 'histrioribus [histrionibus] regiis', that is, 'Queen's minstrels [ie players]', received twenty shillings sometime between Michaelmas 1591 and Michaelmas 1592, that is, between 29 September 1591 and 28 September 1592. The sum is exactly the same as what the 'Queen's players' had received there twice in February and June of the previous year 1591. I am grateful to Jane Harris, Senior Archivist of Hampshire Record Office, for kindly helping me to search for the original document. McMillin and MacLean conjecture that this undated Winchester performance occurred in August 1592 after Southampton but before Bath, in 'Recorded Performances', Queen's Men and their Plays, 183. John Tucker Murray translated the original Latin document, without inferring the exact date. See his English Dramatic Companies 1558-1642, 2 vols (London, 1910), 2.405.

58 James Stokes and Robert J. Alexander (eds), REED: Somerset Including Bath (Toronto, 1996), 1.15. The original record reads 'paid to the quenes plaiers the 22the of August xiiij s. ix d.', but the date of performance ranges '11 June 1592-10 September 1593'. McMillin and MacLean decided that 'As there is no other evidence for the Queen's Men in the south-west in the summer of 1593, the payment has been listed under 
the earlier [1592] of the two possible years', in 'Recorded Performances', Queen's Men and their Plays, 183, 225. 'The Patrons and Performance Web Site' states that 'it cannot be determined whether this was for 1592 or 1593 '.

59 The dates were proposed by McMillin and MacLean, 'Recorded Performances', Queen's Men and their Plays, 182. The dates described in 'The Patrons and Performance Web Site' range '29 Sept.1591-28 Sept.1592'. See also Audrey Douglas and Peter Greenfield (eds), REED: Cumberland, Westmorland, Gloucestershire (Toronto, 1986), 312.

60 For more details of the problem of dating, see Giles E. Dawson (ed.), Collections: Volume VII, The Malone Society Reprints (Oxford, 1965), xxiii.

61 Chambers, Elizabethan Stage, 4.310-11.

62 Francis Berkeley Young, Mary Sidney Countess of Pembroke (London, 1912), 150204; Margaret Patterson Hannay's article in The Oxford Dictionary of National Biography Online (http://www.oxforddnb.com/, 2004-13).

63 Chambers, Elizabethan Stage, 3.337. John Aubrey mentioned, in his BriefLives, that 'She was a great chymist and spent yearly a great deale in that study', cited in Young, Mary Sidney, 154.

64 Michael G. Brennan and Noel J. Kinnamon, A Sidney Chronology 1554-1654 (Basingstoke, 2003), 134. DOI: http://dx.doi.org/10.1057/9780230005723

65 Margaret P. Hannay, Noel J. Kinnamon, and Michael G. Brennan (eds), The Collected Works of Mary Sidney Herbert Countess of Pembroke, 2 vols (Oxford, 1998), 1.37 .

66 Margaret P. Hannay, Philip’s Phoenix: Mary Sidney, Countess of Pembroke (Oxford, 1990), 124.

67 The dated letter from the Vice-Chancellor and Head of Houses at Cambridge to Lord Burghley informs us of their complaint about the disorders and spread of plague to be caused during Sturbridge Fair by 'the Players ... whereof one Dutton is A principale'. See Nelson, REED: Cambridge, 1.340.

68 MacLean, 'Adult Playing Companies', 45.

69 Karl P. Wentersdorf, 'The Origin and Personnel of the Pembroke Company', Theatre Research International 5 (1979-80): 45-68, esp. 61. DOI: http://dx.doi.org/10.1017/ S0307883300000365 